\title{
TERMINASI HUBUNGAN KONSELING
}

\author{
Riem Malini Pane \\ Prodi Bimbingan Konseling Islam \\ Fakultas Dakwah dan Ilmu Komunikasi IAIN Padangsidimpuan \\ (E-mail: riemmalini@gmail.com)
}

\begin{abstract}
Termination is one of the stages in counseling where counselor should end counseling, this decision can be done unilaterally or together. It's a sign that something has been done. As for the stages in termination is to start a new experience, previous experience must be solved and solved, maintain the changes that have been achieved and develop expertise to solve problems that have been obtained from counseling, and act as a reminder that the client is an adult. In termination has several issues, namely termination of individual sessions that serve as a time to determine the next service schedule, and counseling relationships that serve as an important point need to be considered when deciding whether to terminate counseling or not. In addition to the termination issues, there are also some types of counseling terminations that need to be noticed by a counselor that is premature termination, termination of initiative, and termination counselor with a positive note.

Keyword: Termination, Relationships, Counseling
\end{abstract}

\begin{abstract}
Abstrak
Terminasi adalah salah satu tahap dalam konseling dimana konselor harus mengakhiri konseling, keputusan ini dapat dilakukan sepihak atau bersama. Terminasi adalah tanda bahwa sesuatu telah selesai dilakukan. Adapun tahapantahapan pada terminasi adalah untuk memulai pengalaman baru, pengalaman terdahulu harus diselesaikan dan dipecahkan, mempertahankan perubahan yang telah dicapai dan mengembangkan keahlian untuk memecahkan masalah yang telah didapat dari konseling, serta bertindak sebagai pengingat bahwa klien adalah orang dewasa. Di dalam terminasi memiliki beberapa isu, yaitu terminasi sesi individual yang berfungsi sebagai waktu menentukan jadwal pelayanan berikutnya, dan hubungan konseling yang berfungsi sebagai point penting perlu diperhatikan saat memutuskan apakah akan menerminasi konseling atau tidak. Di samping isu terminasi, juga ada beberapa jenis terminasi konseling yang perlu diperhatikan seorang konselor yaitu terminasi prematur, terminasi inisiatif, dan konselor pengakhiran dengan catatan positif.
\end{abstract}

Kata Kunci: Terminasi, Hubungan, Konseling 


\section{A. Pendahuluan}

Konseling adalah suatu proses yang dipandu oleh teori. ${ }^{1}$ Kegiatan konseling terdiri atas serangkaian proses yang dilakukan antara konselor dan klien (konseli) dan didasarkan pada teori-teori konseling sebagai landasan pemberian layanan. Proses konseling berkembang dalam tahap yang dapat didefinisikan dengan transisi yang dapat dikenali. Tahap pertama mencakup membangun suatu hubungan dan memfokuskan diri untuk mendapat partisifasi klien dalam mengeksplorasi isu-isu yang langsung mempengaruhinya. Sedangkan menurut Gibson dalam bukunya bahwa proses konseling merupakan fase-fase yang meliputi: membangun hubungan, pengidentifikasian dan pengeksplorasian problem, lalu merencanakan solusi problem dan bantuan, kemudian diakhiri tindakan dan penutupan sesi konseling. ${ }^{2}$ Sehingga, dalam proses konseling diharapkan adanya hubungan kerjasama yang baik; dimana klien merasa bebas mengemukakan atau mengekspresikan dan menyatakan isu-isu yang menyangkut dirinya. Selain itu dapat membantu mereka memecahkan masalahnya sendiri, kemungkinan juga ada tujuan-tujuan yang mereka inginkan. Oleh karena itu kepercayaan dan kerahasiaan klien sangat perlu diperhatikan oleh konselor.

Membina hubungan sangatlah penting. Konseling adalah bentuk khusus dari hubungan atau komunikasi interpersonal. Berarti kaidah-kaidah yang berlaku untuk komunikasi, berlaku juga dalam konseling. Suatu istilah yang banyak dipakai berkaitan dengan membangun hubungan dalam konseling adalah Rapport. Konselor diharapkan dapat menciptakan rapport dengan kliennya. Rapport adalah suatu iklim psikologis yang positif, yang mengandung kehangatan dan penerimaan, sehingga klien tidak merasa terncam berhubungan dengan konselor.

Adakalanya dalam konseling terlaksana dengan baik dan adakalanya pula konseling terlaksana tidak sesuai dengan yang direncanakan. Jadi, ada istilah dalam konseling yang dinamakan dengan Terminasi konseling. Terminasi ini dapat dikatakan sebagai pengakhiran atau menghentikan proses konseling, yang dapat dilakukan baik di tahap awal, tahap pertengahan maupun tahap pengakhiran

\footnotetext{
${ }^{1}$ Samuel T. Gladding, Konseling Profesi yang Menyuluruh, (Jakarta: 2015)

2 Robert L. Gibson \& Marianne H. Mitchell, Bimbingan dan Konseling, (Pustaka Pelajar: 2012)
} 
yang kadang kala disepakati konselor dan klien maupun sepihak, baik disukai maupun tidak disukai.

\section{B. Landasan Teoritis}

\section{Pengertian Terminasi}

Terminasi adalah salah satu tahap dalam konseling dimana konselor harus mengakhiri konseling, keputusan ini dapat dilakukan sepihak atau bersama. Terminasi merupakan aspek konseling yang paling sedikit dibahas. Kebanyakan konseling dianggap sudah selesai apabila klien merasa sudah puas dan tidak memiliki masalah lagi. Tapi terminasi hubungan konseling mempunyai dampak pada semua pihak yang terlibat, dan biasanya kompleks serta rumit. Menurut Kottler, Sexton, \& Whiston, 1994 dalam Gladding, Terminasi menghasilkan perasaan campur aduk pada konselor, maupun klien. Terminasi mempunyai kekuatan melukai dan menyembuhkan. ${ }^{3}$

Terminasi juga merupakan pintu masuk bagi kontak selanjutnya yang akan datang. Kita akui itu merupakan proses pemecahan masalah secara terus menerus. Terminasi sering menjadi proses yang mengharukan. Hal ini disebabkan karena relasi yang baik dan cukup mendalam diantara konselir dengan kliennya. Perpisahan dengan orang yang akrab,dekat dalam pemecahan masalah dirasakan sangat berat dan memilukan hati, klien juga akan merasa ragu dan kurang yakin akan kemampuannya dalam melaksanakan fungsi dan tugas kehidupan selanjutnya tanpa dukungan para konselor yang sudah membantunya untu menemukan solusi dari berbagai masalah yang dihadapinya. Oleh sebab itu para konselor perlu melakukan tekanan psikologi dengan cermat dan mengamati menifestasi emosional klien dengan hati hati.

Dari uraian di atas, dapat diambil suatu pengertian bahwa Terminasi merupakan Tahapan dalam mengakhiri atau menghentikan proses konseling. Dalam hal ini Terminasi sangat penting diperhatikan oleh konselor untuk mengetahui apakah klien benar-benar sudah merasa puas dengan konselingnya atau sebaliknya, baik terminasi ini dilakukan oleh konselor atau klien.

${ }^{3}$ Samuel T. Gladding. Konseling Profesi yang Menyeluruh.Jakarta: PT. Indeks, 2012. 


\section{Fungsi Terminasi}

Terminasi dalam konseling memiliki beberapa fungsi penting antara lain: ${ }^{4}$

a. Terminasi adalah tanda bahwa sesuatu telah selesai dilakukan. Untuk memulai pengalaman baru, pengalaman terdahulu harus diselesaikan dan dipecahkan.

b. Terminasi berarti mempertahankan perubahan yang telah dicapai dan mengembangkan keahlian untuk memecahkan masalah yang telah didapat dari konseling.

c. Terminasi bertindak sebagai pengingat bahwa klien adalah orang dewasa.

\section{Langkah-langkah Terminasi}

Menurut Lesmana, langkah-langkah terminasi yang dilakukan adalah: ${ }^{5}$

a. Persiapan Verbal

Konselor harus mempersiapkan diri klien melalui ungkapan-ungkapan yang mengandung makna bahwa konseling akan segera diakhiri. Apabila klien menolak dan mengatakan bahwa ia masih membutuhkan bantuan konselor, maka konselor harus waspada dan harus meyakinkan klien dengan ungkapan verbal. Contohnya: "Baiklah, saya telah menyaksikan sendiri kalau anda telah mengalami kemajuan yang cukup signifikan dan perubahan perilaku ke arah yang lebih positif'. Hal penting yang harus dipersiapkan oleh konselor adalah mempersiapkan ringkasan akhir yang menyimpulkan proses konseling secara keseluruhan.

b. Membuka Jalur untuk Kemungkinan follow-up

Pernyataan terakhir konselor merupakan penekanan diberlakukannya follow-up dengan catatan bahwa sesi konseling selanjutnya adalah untuk mendiskusikan kemajuan klien sesuai dengan strategi intervensi yang dilakukan. Follow-up juga digunakan untuk meyakinkan klien bahwa konselor tidak hanya ada di saat klien berada dalam tekanan/masalah, tetapi konselor juga akan membantu klien untuk mendukung kemajuan-kemajuan yang telah diperolehnya selama menjalani konseling.

\footnotetext{
4 Ibid.

${ }^{5}$ Lesmana, Jeanette Murad.2005. Dasar- dasar Konseling. Jakarta: Universitas Indonesia ( UI- Press)
} 
c. Pamit Secara Formal ( Formal Leave-Taking). Berpamitan kepada klien adalah hal yang perlu diperlukan:

1) Konselor menyampaikan terima kasih kepada klien karena memberinya kesempatan untuk membantu menyelesaikan masalah klien.

2) Menyampaikan permohonan maaf apabila ada kekeliuran yang dilakukan konselor selama proses konseling berlangsung.

3) Memberi dukungan dan sugesti pada klien agar tetap mempertahankan kemajuan yang telah diperolehnya selama menjalani konseling.

Dari Uraian diatas langkah-langkah Terminasi konseling harus dilakukan secara tepat dan yang paling penting bahwa dalam melakukan terminasi tidak dilakukan secara tiba-tiba tapi direncanakan dengan strategi dan taktik yang benar dan tepat.

\section{Prinsip Prosedur Terminasi Agar Positif}

Agar terminasi dalam tahapan proses pertolongan pekerjaan sosial berjalan lancar dan positif maka terdapat prinsip procedural yang harus dilaksanakan. Prinsip prosedural terminasi tersebut sebagai berikut :

a. Terminasi hendaknya berdasarkan asesmen dan keputusan bersama.

b. Pengalaman terminasi hendaknya mengandung tujuan spesifik dan konkrit dengan segala konsekuensinya.

c. Klien hendaknya dipersiapkan menghadapi terminasi sehingga tidak bergantung terus kepada pekerja sosial dan dapat hidup mandiri.

d. Klien hendaknya dibantu mengembangkan kemampuan problem solving atau pemecahan masalah agar dapat berperan aktif dalam proses pertolongan dan nantinya akan dapat memecahkan masalahnya sendiri bila berhadapan lagi dengan masalah.

e. Sistim intervensi hendaknya diberikan dengan mengkaitkan klien kepada sistem sumber dan penguasaan akses agar tercipta pemecahan masalahan sehingga dapat meningkatkan keberfungsian klien.

Ada beberapa prosedur dasar yang dibutuhkan dalam tugas umum, antara lain : 
a. Pemindahan harus didasarkan pada kebutuhan bersama adanya saling memahamidalam program pertolongan dan situasi pada waktu keputusan dibuat dalamterminasi.

b. Pengalaman terminasi hendaknya mempunyai sasaran pertolongan secara spesifik dan akibat-akibatnya untuk kelayan.

c. Klien hendaknya bersiap-siap menghadapi atau disiapkan dan ditolong dengantata cara terminasi.

d. Klien harus dianjurkan secara terus-menerus untuk memecahkan masalah, belajar dan pertumbuhan proses dirinya sendiri dengan pertolongan sumber petolongan baru.

e. Sistem intervensi harus diterminasikan dalam cara-cara bahwa hubungan kliendengan masyarakat haruslah merupakan sistem pertolongan yang alamiah dankemungkinan klien untuk terus menerus memudahkan untuk memperolehsumber.

f. Pekerja sosial atau lembaga sosial hendaknya diperkenalkan untuk menghadapikesulitan di masa depan, kelajutannya adalah kontak yang telah ditetapkan.

g. Pekerja sosial harus mengakui dan memperlakukan dengan perasaannya dalammelakukan terminasi dimana perasaan-perasaan itu menyakitkan dia dapatmenggunakan kepercayaannya untuk menolong memecahkan masalahnya sendirisebagaimana halnya dengan perasaan klien

\section{Penyebab Terminasi}

Apabila proses konseling telah selesai dan tujuan konseling telah tercapai, maka pada saat itulah terminasi dapat dilakukan. Tapi adakalanya penyebab terminasi konseling ini karena tidak memperoleh manfaat dari konseling tersebut. Penyebab terminasi yang dipandang dari sisi konselor dan klien: ${ }^{6}$

a. Terminasi oleh Konselor

1) Sasaran konseling telah tercapai

2) Konselor merasa bahwa klien tidak mengalami kemajuan seperti yang diharapkan, sehingga tidak ada manfaatnya bila konseling tetap dilanjutkan.

\footnotetext{
${ }^{6}$ Namora Lumongga Lubis, Memahami Dasar-Dasar Konseling Dalam Teori dan Praktek, Kencana (Jakarta: Media Prenada Group, 2011). h. 129.
} 
3) Konselor melihat bahwa klien terlalu bersikap dependen (bergantung terus kepada konselor) sehingga tidak mau mengambil tanggungjawabnya terhadap hidupnya sendiri.

b. Terminasi oleh Klien

1) Klien merasa bahwa dirinya telah sembuh walaupun sebenarnya hal tersebut hanya berupa pengurangan simton.

2) Klien merasa telah berhasil sesuai dengan kesepakatan dalam konseling

3) Terjadinya premature termination

4) Klien menolak pengalaman rasa sakit yang terkait dengan konseling atau klien menolak berhadapan dengan bagian dirinya yang tidak disenanginya.

5) Klien tidak memiliki komitmen yang cukup untuk berubah karena untuk berubah klien harus melalui proses yang lama dan menyakitkan

6) Klien tidak memiliki cukup waktu atau keuangan yang tidak mendukung

7) Klien merasa bahwa dirinya tidak mengalami kemajuan sehingga menganggap bila konseling dilanjutkan tidak akan bermanfaat.

Dari penyebab terminasi ini adakalanya dilakukan oleh konselor atau klien dan adakalanya secara bersamaan. Sebaiknya dalam terminasi ini apabila masalah klien sudah tertuntaskan dan klien dapat mandiri kemudian klien tidak menjalani kehidupan yang KES-T (Kehidupan Efektif Sehari-hari - Terhambat), tapi klien menjalani kehidupan KES (Kehidupan Efektif Sehari-hari).

\section{Isu Terminasi}

a. Terminasi sesi individual

Sesi konseling individu biasanya berlangsung selama 40 hingga 50 menit. Benjamin menyebutkan dua faktor penting dalam mengakhiri suatu wawancara, antara lain: ${ }^{7}$

1) Konselor dan konseli menyadari bahwa sesi konseling telah habis

2) Jangan mendiskusikan materi baru di akhir sesi konseling.

Konselor dapat mengakhiri sebuah wawancara dengan efektif melalui beberapa cara, antara lain :

${ }^{7}$ Eti Nurhayati, BimbinganKonselingdanPsikoterapilnovatif, Yogyakarta: Pustaka Pelajar, 2011), h. 48. 
1) Membuat pernyataan singkat yang menandakan bahwa sesi konseling berakhir

2) Konselor menggunakan bahasa tubuh untuk menunjukkan bahwa sesi telah berakhir.

Suatu bagian penting dalam terminasi sesi individu adalah menentukan jadwal perjanjian berikutnya.Akan lebih mudah dan lebih efisien jika mereka menentukan pertemuan berikutnya pada akhir sesi daripada melakukan melalui telepon.

b. Terminasi hubungan konseling

Menurut Maholick dan Turner hal spesifik yang perlu diperhatikan saat memutuskan apakah akan menerminasi konseling atau tidak, antara lain :

1) Memeriksa apakah permasalahan konseli telah berkurang

2) Menentukan apakah perasaan yang menimbulkan stres sudah hilang

3) Menilai kemampuan konseli menghadapi masalah dan tindakan pemahaman terhadap diri sendiri dan orang lain

4) Menentukan apakah konseli mampu berhubungan lebih baik dengan orang lain dan mampu mengasihi dan dikasihi

5) Memeriksa apakah konseli telah mendapatkan kemampuan untuk merencanakan dan bekerja dengan lebih produktif

6) Mengevaluasi apakah konseli dapat berfungsi lebih baik dan menikmati kehidupan.

\section{Jenis Terminasi Konseling}

a. Terminasi Prematur

Menurut Ward, terminasi prematur tidak bisa diukur berdasarkan jumlah sesi yang telah diselesaikan konseli, melainkan lebih berhubungan dengan seberapa baik konseli telah mencapai tujuan pribadi yang telah ditetapkan pada awal proses konseling dan seberapa baik dia berfungsi secara umum.

Gejala konseling ingin mengadakan terminasi prematur, ditunjukkan dengan cara :

1) Meminta konseling dihentikan setelah sesi pertama

2) Datang terlambat pada sesi yang telah disepakati

3) Tidak datang pada sesi yang telah disepakati 
Hansen, Warner, dan Smith menyarankan agar topik terminasi prematur dibicarakan secara terbuka antara konseli dan konselor, jika konseli mengekspresikan keinginan untuk mengadakan terminasi prematur. Jika konselor menemukan bahwa konseli ingin berhenti, wawancara keluar harus disiapkan. Ward menyebutkan 4 keuntungan yang bisa didapatkan dari wawancara ini, antara lain:

1) Membantu konseli memecahkan perasaan negatif yang berasal dari pengalaman konseling

2) Sebagai satu cara untuk mengundang konseli melanjutkan konseling jika konseli masih menginginkan

3) Bentuk lain dari perawatan atau konselor lain dapat disertakan dalam wawancara keluar sebagai pertimbangan bagi konseli jika konseli menginginkannya

4) Meningkatkan peluang bahwa dilain waktu ketika konseli membutuhkan bantuan, dia akan kembali untuk mencari bantuan konseling.

Terminasi prematur, sering kali membuat konselor kesalahan, yaitu menyalahkan diri sendiri maupun konseli. Untuk menghindari kesalahan tersebut Cavanagh merekomendasikan agar konselor mencari tahu mengapa konseli mengakhiri konseling secara prematur. Alasan terminasi dapat mencakup sebagai berikut :

1) Untuk melihat apakah konselor benar-benar peduli

2) Mencoba untuk meningkatkan perasaan positif dari diri konselor

3) Untuk menghukum atau menyakiti konselor

4) Untuk menghilangkan ansietas

5) Untuk menunjukkan kepada konselor bahwa konseli telah menemukan perawatan di tempat lain

6) Untuk mengekspresikan kepada konselor bahwa konseli merasa tidak dipahami.

Ada beberapa variabel sering kali efektif untuk mencegah terjadinya terminasi prematur, antara lain: ${ }^{8}$

\footnotetext{
${ }^{8}$ Mc John Leod. Pengantar Konseling, (Jakarta: Kencana, 2012), h. 90.
} 
a) Temu janji

b) Orientasi pada konseling

c) Konsisten konselor

d) Pengingat untuk memotivasi kehadiran konseli.

\section{b. Terminasi Inisiatif Konselor}

Terminasi atas inisiatif konselor adalah lawan dari terminasi prematur. Beberapa alasan konselor mengakhiri proses konseling, diantaranya sakit, bekerja melalui countertransference, relokasi ke arah lain, menyadari kebutuhan konseli dapat dipenuhi oleh orang lain. Ada juga alasan buruk konselor untuk melakukan terminasi, diantaranya kemarahan, kebosanan atau ansietas. Jika konselor mengakhiri hubungan karena perasaan semacam ini, konseli akan merasa ditolak dan merasa lebih buruk lagi. Konseli dan konselor seharusnya mempersiapkan diri sedini mungkin untuk menghadapi terminasi sementara dengan mendiskusikan secara terbuka peristiwa yang akan terjadi dan mengatasi perasaan yang mendalam sehubungan dengan perpisahan tersebut dengan cara mempersiapkan konseli lebih terstruktur dalam menghadapi terminasi yang diinisiatifkan konselor. Pada situasi semacam ini sangatlah penting memastikan bahwa konseli memiliki nama dan nomor telepon konselor lain untuk membantunya dalam keadaan darurat.

c. Pengakhiran dengan Catatan Positif

Empat panduan yang dapat digunakan oleh konselor untuk mengakhiri suatu hubungan konseling yang intens dalam suatu cara yang positif, antara lain :

1) Sadar akan kebutuhan dan keinginan konseli dan memberikan waktu pada konseli untuk mengekspresikannya

2) Meninjau ulang peristiwa penting dalam konseling dan membawa hasil tindakan tersebut ke saat ini.

3) Mengakui dan mendukung perubahan yang telah dilakukan oleh konseli

4) Meminta kontak lanjutan.

\section{Masalah yang Berhubungan dengan Terminasi}

a. Tindak lanjut

Tindak lanjut melibatkan pengecekan untuk melihat bagaimana pekembangan konseli, dalam kaitannya dengan semua permasalahan yang ada, 
beberapa saat setelah terjadi terminasi. Inti dari tindak lanjut adalah proses pemantauan positif yang mendorong pertumbuhan konseli.

Ada empat cara tindak lanjut, antara lain :

1) Mengundang konseli untuk sesi guna membicarakan kemajuan yang diperoleh dalam mencapai tujuan konseling.

2) Menghubungi konseli melalui telepon.

3) Mengirinkan surat kepada konseli untuk menanyakan keadaan konseli sekarang.

4) Hubungan lebih impersonal dengan mengirim surat yang berisi daftar pertanyaan tentang kondisi konseli.

b. Rujukan dan daur ulang

Rujukan adalah mengatur bantuan lain bagi konseli ketika perjanjian awal tidak berjalan lancar atau tidak membantu. Menurut Golstein (dalam Gladding) ada banyak alasan untuk melakukan rujukan, termasuk yang disebut di bawah ini ${ }^{9}$ :

1) Konseli mempunyai masalah yang tidak dapat diselesaikan oleh konselor

2) Konselor belum berpengalaman pada bidang tertentu dan tidak mempunyai keahlian yang memadai untuk membantu konseli

3) Knselor mengenal orang yang lebih ahli yang dapat lebih membantu konseli

4) Konselor dan konseli mempunyai kepribadian yang tidak cocok

5) Hubungan antara konseli dan konselor mengalami kebuntuan pada tahap awal konseling.

Rujukan melibatkan beberapa kata pertanyaaan, antara lain:

1) Bagaimana, mencakup menghubungi sumber daya yang lebih membantu dan menangani konseli untuk memaksimalkan kesempatan yang akandia dapatkan dengan proses rujukan.

2) Kapan merujuk melibatkan waktu yang tepat untuk dirujuk.

3) Siapa, melibatkan orang kepada siapa Anda merujuk konseli.

Daur ulang adalah suatu alternatif ketika konselor menganggap meski proses konseling belum berjalan dengan baik tetapi masih dapat diperbaiki. Hal tersebut berarti memeriksa ulang semua tahap proses terapi.

\footnotetext{
${ }^{9}$ T Samuel Gladding. Op.Cit, h. 223.
} 


\section{Hubungan Konseling}

\section{Faktor-faktor yang mempengaruhi konseling}

Setiap orang ketika melakukan sesuatu kegiatan dilandasi akan dorongan dari dalam dan dari luar individu. Crow and Crow dalam Abdul Rahman Shaleh \& Muhlib Abdul Wahab menjelaskan faktor-faktor yang mempengaruhi timbulnya minat meliptui:

a. Dorongan dari dalam diri individu.

b. Motif sosial, dapat menjadi faktor yang membangkitkan minat untuk melakukan suatu aktivitas tertentu.

c. Faktor emosional, minat mempunyai hubungan yang erat dengan emosi. ${ }^{10}$

Sejumlah faktor dapat mempengaruhi konseling, membuatnya lebih baik atau lebih buruk. Hal yang dibahas disini adalah keseriusan masalah yang dipaparkan, struktur, inisiatif, latar fisik, kualitas klien, dan kualitas konselor

a. Keseriusan masalah yang dipaparkan

Konseling dipengaruhi oleh keseriusan masalah yang dipaparkan klien. Dalam Leibert, dijelaskan bahwa "Bukti menunjukkan adanya hubungan antara seberapa besar masalah yang dipaparkan klien dengan perkembangan pengobatan. Jadi, klien yang melaporkan tingkat gangguan yang tinggi menjalani lebih banyak sesi untuk mencapai kemajuan yang signifikan daripada klien yang melaporkan tingkat ganggguan yang lebih rendah"11

b. Struktur

Day dan Sparacio, menjelaskan "Struktur dalam konseling didefinisikan sebagai kesepahaman bersama antara konselor dan klien mengenai karakteristik, kondisi prosedur, dan parameter konseling”. Sedangkan ahli lain yakni Brammer dan Shostrom, menjelaskan bahwa "Struktur membantu memperjelas hubungan antara konselor dan klien dan memberikan arah yang benar; melindungi hak,

${ }^{10}$ Abdul Rahman Shaleh \& Muhlib Abdul Wahab, Psikologi Suatu Pengantar Dalam Perspektif Islam (Jakarta: PT. Prenada media, 2004), h. 264

${ }^{11}$ T Samuel Gladding.Konseling Profesi yang Menyeluruh.(Jakarta: PT. Indeks, 2012), h. 148. 
peran, dan kewajiban baik dari konselor maupun klien; dan memastikan suksesnya konseling,"12

c. Inisiatif

Inisiatif dapat disebut juga sebagai motivasi untuk berubah.Menurut para ahli kebanyakan klien datang untuk konseling atas dasar kemauan sendiri, namun tidak jarang pula yang datang dengan tekanan dan kehawatiran dan memaksakan diri untuk melakukan sesi konseling bahkan ada juga yang enggan berpartisipasi dalam kegiatan konseling. Menurut Vriend danDyer "memperkirakan keengganan dalam berbagai tingkat pada mayoritas klien yang datang ke konselor"13.

Dalam menangani klien yang enggan melakukan konseling terkadang konselor bingung harus berbuat seperti apa. Hal ini mendorong konselor untuk menyalahkan klien terhadap permasalahannya dan tidak jarang pula konselor menyalahkan diri sendiri ketika tidak berhasil menyelesaikan permasalahan yang dialami klien. Untuk megatasi hal seperti ini konselor harus sering berlatih membayangkan dirinya sebagai klien yang datang dengan paksaan sehingga konselor mampu merasakan apa yang dirasakan klien semacam ini dan dapat menumbuhkan rasa empati konselor. Ritchie, menjelaskan bahwa klien yang enggan adalah "seseorang yang dirujuk oleh pihak ketiga dan sering kali kurang mempunyai motivasi untuk mencari pertolongan". Dalam hal ini disamping konselor memiliki rasa simpati juga harus memiliki rasa empati tingkat tinggi.

d. Latar fisik

Latar fisik ini terkait dengan tempat pelaksanaan bimbingan dan konseling, pada dasarnya kegiatan konseling dapat dilakukan dimana saja namun kebanyaka kegiatan konseling dilakukan didalam ruangan. Benjamin, mengatan dia melakukan konseling didalam sebuah tenda.Menurutnya, tidak ada kualitas tertentu yang wajib dimiliki sebuah ruangan "kecuali bahwa ruangan tersebut tidak boleh membuat gelisah, berisik atau menyebabkan gangguan ${ }^{14,}$.

\footnotetext{
12 Ibid, h. 149.

13 Ibid, h. 153.

14 Ibid, h. 157.
} 
Dalam tinjauan ekstensif terhadap penelitian latar fisik dan konseling, pressly dan Heesacker meneliti delapan karakteristik arsitektural dari ruangan dan dampak potensialnya pada sesi konseling.

Latar fisik ini juga sangat menentukan pelaksanaan proses konseling karena dengan ruangan yang nyaman, tenang dapat membuat hubungan konseling antara konselor dan klien dapat tercapai dengan baik dan harmonis.

\section{e. Kualitas klien}

Hubungan konseling diawali sejak kesan pertama. Cara konselor dan klien saling berkenalan merupakan hal yang vital dalam membangun sebuah hubungan yang produktif. Menurut Warnath menunjukkan bahwa "klien datang dalam beragam ukuran, bentuk, karakteristik kepribadian, dan tingkat ketertarikan”. Beberapa klien terkadang sukses dalam menjalankan kegiatan konseling, namun tidak jarang klien yang tidak sukses dalam konseling yang dilakukan. Kelompok yang cenderung sukses adalah kelompok dengan ciri; muda, atraktif, berani berbicara, cerdas, dan sukses.Sedangkan kelompok yang cenderung tidak sukses dalam kegiatan konseling adalah kelompok dengan ciri; orang rumahan, tua, kurang cerdas, jarang bicara, kurang berkemampuan, bodoh, dan kurang pandai. Konselor juga harus paham bahwa klien banyak aneka ragamnya, mulai dari klien sukarela, terpaksa, enggan, krisis sampai bermusuhan. Jadi, konselor juga harus cerdas menghadapi setiap klien yang datang.

f. Kualitas konselor

Menurut Cavanagh mengemukakan bahwa kualitas pribadi konselor ditandai dengan beberapa karakteristik sebagai berikut : (a) Pemahaman diri; (b) kompeten; (c) memiliki kesehatan psikologis yang baik; (d) dapat dipercaya; (e) jujur; (f) kuat; (g) hangat; (h) responsif; (i) sabar; (j) sensitif; dan (k) memiliki kesadaran yang holistik. ${ }^{15}$ Sedangkan menurut Furqon ditemukan bahwa konselor sekurang-kurangnya perlu memiliki tiga kompetensi, di samping perlu dukungan kondisi yang kontekstual dan lingkungan, yaitu kompetensi pribadi (personal competencies), kompetensi inti (core competencies), dan kompetensi pendukung

\footnotetext{
${ }^{15}$ Michael E. Cavanagh, The Counseling Experience, (1982)
} 
(supporting competencies). ${ }^{16}$ Kompetensi pribadi (personal competencies) merujuk kepada kualitas pribadi konselor yang berkenaan dengan kemampuan untuk membina hubungan baik antarpribadi (rapport) secara sehat, etos kerja dan komitmen profesional, landasan etik dan moral dalam berperilaku, dorongan dan semangat untuk mengembangkan diri, serta berkaitan dengan kemampuan untuk melakukan pemecahan masalah.

Pribadi konselor merupakan 'instrumen' yang menentukan bagi adanya hasil yang positif dalam proses konseling. Kondisi ini akan didukung oleh keterampilan konselor mewujudkan sikap dasar dalam berkomunikasi dengan konselinya. Pemaduan secara harmonis dua instrumen ini (pribadi dan keterampilan) akan memperbesar peluang keberhasilan konselor. Oleh karenanya, konselor merupakan ujung tombak dalam kegiatan konseling, sehingga kemampuan seorang konselor sangatlah diprioritaskan dalam setiap kegiatan konseling yang dilakukan. Okun dan Kantrowitz mencatat bahwa "sangatlah sulit untuk memisahkan karakteristik kepribadian si penolong dari tingkat dan gayanya dalam bekerja, karena keduanya saling berhubungan".

\section{Kesimpulan}

Dalam menjalin hubungan konseling meliputi kemampuan mengadakan wawancara awal dan mengeksplorasi serta identifikasi tujuan konseling. Dan dalam menjalin hubungan konseling, dipengaruhi beberapa faktor, antara lain: keseriusan maslah, struktur,inisiatif, kualitas konseli dan kualitas konselor. Terminasi ini terjadi setelah tujuan konseling tercapai.Kadang terminasi ini dapat terjadi sebelum tujuan tercapai atau disebut terminasi prematur.Ada juga konselor dan konseli yang enggan mengakhiri hubungan konseling atau menolak terminasi.Penolakan terminasi ini terjadi biasanya karena sudah ada hubungan yang mendalam antara konseli dan konselor.

${ }^{16}$ Furqon, Evaluasi Belajar Di Sekolah, Mimbar Pendidikan No.3 Tahun XX, (Bandung:Universitas Pendidikan Indonesia, 2001) 


\section{Daftar Referensi}

Abdul Rahman Shaleh \& Muhlib Abdul Wahab, Psikologi Suatu Pengantar Dalam Perspektif Islam, Jakarta: PT. Prenada Media, 2004

Eti Nurhayati, Bimbingan Konseling dan Psikoterapi Inovatif, Yogyakarta: Pustaka Pelajar, 2011.

Furqon, Evaluasi Belajar di Sekolah, Mimbar Pendidikan No.3 Tahun XX, Bandung: Universitas Pendidikan Indonesia, 2001

Lesmana, Jeanette Murad, Dasar- Dasar Konseling, Jakarta: Universitas Indonesia Press, 2005.

Mc John Leod.Pengantar Konseling, Jakarta: Kencana, 2012.

Michael E. Cavanagh, The Counseling Experience, 1982.

Namora LumonggaLubis, Memahami Dasar-Dasar Konseling Dalam Teori dan Praktek, Jakarta: Kencana, 2011.

Robert L. Gibson \& Marianne H. Mitchell, Bimbingan dan Konseling, Pustaka Pelajar, 2012

Samuel T. Gladding, Konseling Profesi yang Menyuluruh, Jakarta, 2015 